\title{
MICROINSURANCE IN LIMITING INSURANCE EXCLUSION
}

\begin{abstract}
ANNA BERA
University of Szczecin, Faculty of Management and Economics of Services, POLAND

e-mail: anna.bera@wzieu.pl

RECEIVED

ACCEPTED

JEL

CLASSIFICATION

KEYWORDS

ABSTRACT

10 December 2018

28 December 2018

$\mathrm{G} 15, \mathrm{G} 22, \mathrm{G} 32$

insurance exclusion, microinsurance, poverty reduction

Microinsurance provides indigent households with protection against basic threats, especially in developing countries. When compared to the general population, poor households are usually more often subject to risk such as illnesses, accidents or property losses, and are therefore more dependent on insurance services. However, due to their low economic attractiveness, they are often not served by traditional insurance companies. In Europe, particularly Central and Eastern Europe, microinsurance is a relatively new concept that is developing comparatively slowly. Thus, this situation constitutes an opportunity to develop a microinsurance system that can become an active instrument in reducing the risk of insurance exclusion in developing and developed countries.The purpose of the article is the micro-insurance specifics in the aspect of insurance exclusion. The research process required the use of the following research methods and techniques: critical literature analysis, desk research, observation, qualitative methods and graphic presentation techniques of research and analysis results. The main conclusions that flow from the article is an opportunity to develop micro-insurances not only in poor countries. They give the opportunity to increase the insurance capacity of insurers. It is also a chance to have insurance coverage by a larger group of households.
\end{abstract}

\section{Introduction}

Financial exclusion is a social problem faced by both developing and developed countries. This phenomenon is related to the inability of some social groups to access basic financial services in a proper way. It covers a wide range of social groups that for various reasons do not use insurance products at all or use them insufficiently. At the same time, it can be observed that in the financial market the problem of insurance exclusion is treated as a matter 
of secondary importance, which increases the relatively low confidence in insurance institutions. Microinsurance may be a solution, as it is understood as a simple product with high development potential. Nevertheless, this requires a certain remodelling of the market and creating an offer tailored to the needs of those affected by the insurance exclusion. Moreover, of necessity are systemic measures, which are subject to the competence of institutional entities operating on the insured market.

\section{Materials and method}

The research process required the use of the following research methods and techniques: critical literature analysis, desk research, observation, qualitative methods and graphic presentation techniques of research and analysis results. The analysis of the literature aimed at assessing the state of knowledge about the phenomenon of insurance exclusion and microinsurance. In the phase of gathering the actual knowledge, desk research method was used, and as a result, the most commonly used solutions in the field of microinsurance were selected. When examining industry reports (Swiss $\mathrm{Re}$ ) and analysing the available statistics, conclusions were drawn about the possible use of these instruments and further prospects for them. Furthermore, the available microinsurance products have also been identified. On this basis, final conclusions were formulated.

\section{Insurance exclusion against the background of financial exclusion}

Financial exclusion is a social problem faced by both developing and developed countries. This concept is defined by, among others, E. Kempson and C. Whyley, who understand financial exclusion as a limited access to mainstream financial services, without focusing on physical or geographical barriers (Kempson, Whyley, 1999, pp. 5-8). On the other hand, the European Commission refers to the definition presented in the "Financial Services Provision and Prevention of Financial Exclusion" (2008) report, according to which, financial exclusion refers to a process whereby people encounter difficulties accessing and/or using financial services and products in the mainstream market that are appropriate to their needs and enable them to lead a normal social life in the society in which they belong. In this definition, the focus is put on entities providing services on the main market. For example, as far as the banking market is concerned, one can talk about strictly basic and alternative markets (secondary), whereas in the case of insurance products, such markets simply do not exist. Thus, insurance solutions in the context of financial exclusion remain the domain of insurance companies operating in the main market.

On the other hand, insurance exclusion can be understood as a situation in which a group of people does not use insurance products at all. This may take place for a variety of reasons. First of all, it is conditioned by the lack of an offer tailored to the needs of people affected by this type of exclusion and a physical lack of access to products. It may directly result from the fact that financial capabilities of such people are very limited. Furthermore, the poor and people suffering from bad financial situation are often unable to reduce their consumption in order to pay an insurance premium. Thus, despite the higher usefulness of insurance, they do not acquire the necessary insurance protection (Solarz, 2011, pp. 363-371).

Insurance exclusion is also aggravated by social reasons, such as aging of society and a technology gap. It is also the result of low awareness and economic knowledge in the field of insurance, which for many people seems to be too difficult and incomprehensible. There is also a group of people who voluntarily stop using insurance products, thus self-excluding themselves. This mainly stems from the previous negative experience with insurance institutions and the resulting loss of trust. 
Furthermore, the exclusion from the insurance market is very often caused by the insurers themselves. As commercial intermediaries whose goal is to maximize profits, they concentrate their activities mainly on clients to whom they can sell the most profitable products. When looking for the best benefit-cost ratio, they limit the service to those who absorb resources without generating the expected benefits. Hence the strong concentration of insurance branches in cities and their negligible number in remote locations and rural areas. Another reason is that insurance companies often do not adapt their offer to the needs of potential clients, as well as demand too high prices for insurance products. Moreover, poorly educated households often perceive the insurance premium as an unnecessary and excessive expense. It should be pointed out that the prices of basic insurance in relation to earnings in Poland have been among the highest in Europe for years. At the same time, according to the Social Diagnosis 2015 , trust in life insurance companies is at the level of $48.7 \%$, whereas in the case of property insurance companies it amounts to $34.4 \%$, and is definitely lower than trust in banks, for which it reaches the level of $77.2 \%$ (Czapiński, Panek, 2015, pp. 151-153). Thus, the phenomenon of insurance exclusion is additionally strengthened by low trust of customers in the insurance institution itself.

\section{Social groups vulnerable to insurpance exclusion}

About $50.5 \%$ of the world's population aged 15 and more is subject to financial exclusion. Although this phenomenon mainly concerns developing countries, it also occurs in the European Union. According to world statistics, at least 1.5 to 3 milliard people for various reasons do not have any insurance policy protecting their lives, health or property against the negative effects of fortuitous events (Eling, Biener, 2011, pp. 403-404).

Insurance exclusion, as a part of a financial exclusion, usually concerns the following social groups:

- people of low income,

- unemployed people,

- women,

- single parents,

- younger and older people,

- non-employed people due to illnesses,

- the disabled,

- people living in rural or poorly urbanized areas,

- immigrants.

Certainly, low-income households, including the unemployed, are the most vulnerable to insurance exclusion. The next social group that has difficult access to the insurance services market are the elderly as well as the sick and the disabled.

The above-mentioned groups make up a large part of society, however the threat of insurance exclusion does not have to necessarily concern them.

\section{The characteristics and scope of the microinsurance}

Microinsurance is part of microfinance, which originated in developing countries in the 1970s and 1980s. In addition to microcredit and microloans, they are the basic product offered on the so-called microfinance market. These are products targeted at the poorest part of society for whom basic commercial insurance is not available due to financial reasons (Bednarczyk, 2016, pp. 23-32). Microinsurance concerns simple and cheap products 
with a limited scope of insurance protection addressed to people who need insurance in the baseline option. Thus, the origins of microinsurance are related to the Third World countries. They have been well implemented in countries such as India, Bangladesh, China, Brazil, Bolivia, etc. They are also an instrument used by governments and international organizations to reduce and alleviate poverty and financial exclusion in developing countries. Moreover, they constitute a natural mechanism replacing the social safety net (Kawiński, 2010, pp. 311-324). Therefore, microinsurance can be generally defined as simple and cheap insurance products with a limited scope of insurance protection addressed to poor people.

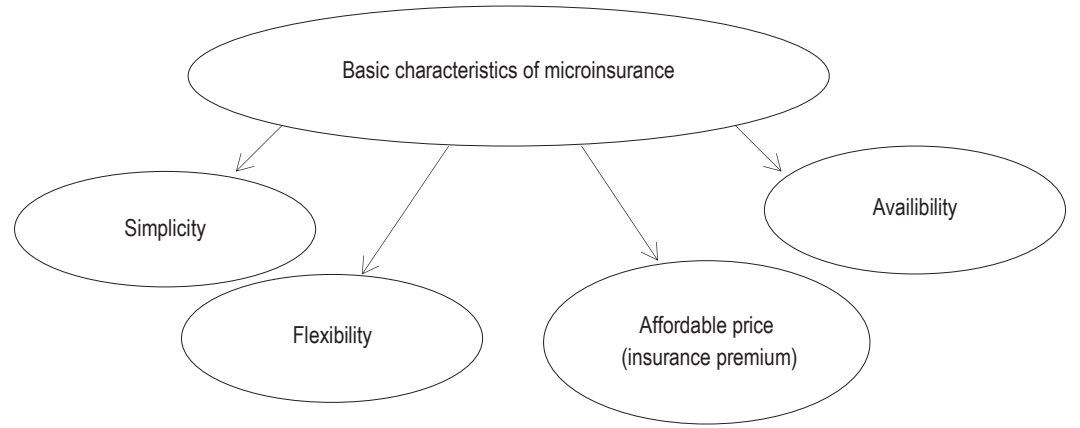

Figure 1. The most important characteristics of microinsurance

Source: own work based on Sigma, Swiss Re (2010).

Accessibility is related to the fact that microinsurance is directed to a special group of people with low, often irregular income. At the same time, in poor households, the risk in such areas as accidents, illness or theft is higher than in a typical household. Affordable price is connected with the fact that the premium for insurance protection should be definitely low, with the possibility of splitting it into instalments. A kind of solution is the involvement of state institutions and subsidizing this type of insurance. Flexibility is related to the fact that the recipients of this type of insurance are primarily people with irregular income and hierarchical goals different from people with a stable financial situation. Therefore, these products should be very well tailored to various recipients' insurance needs. Simplicity, which should be manifested not only in the product structure, but also its distribution and the method of collecting the insurance premium. It concerns both the construction of contracts and general conditions of insurance as well as the principles of claims settlement.

The differences between traditional insurance and microinsurance are presented in Table 1.

Thus, in the light of the presented comparison, the following definitions of microinsurance can be adopted in the article. This term is understood as insurance cover offered to financially marginalised people (low income, the poor) for specific risks, in exchange for an insurance premium calculated on the basis of limited actuarial data, and proportional to the probability and cost of risk. At the same time, alternative channels of distribution (Singh, Bihari, 2018) are the optimal solution for delivering these products to target groups. These include distribution agreements with microfinance institutions and banks, local government and non-government organizations, as well as suppliers of other services, such as post offices, supermarkets, work cooperatives, hospitals, medical centres, schools, etc. 
Table 1. Microinsurance and traditional insurance - differences

\begin{tabular}{|c|c|c|}
\hline & Microinsurance & Traditional insurance \\
\hline Target market & $\begin{array}{l}\text { - natural persons with low income and insurance } \\
\text { knowledge, } \\
\text { - high-risk customers }\end{array}$ & $\begin{array}{l}\text { - persons with middle- and high-income who know and } \\
\text { understand the essence and benefits of insurance } \\
\text { products, } \\
\text { - clients with a fairly well-known risk }\end{array}$ \\
\hline Product characteristics & $\begin{array}{l}\text { - simple insurance products (transparent language, no or } \\
\text { low number of exceptions, low guarantee amount, group } \\
\text { policies), } \\
\text { - premiums calculated based on limited actuarial data }\end{array}$ & $\begin{array}{l}\text { - extensive products, various general insurance } \\
\text { conditions with multiple liability inclusions, } \\
\text { - premiums calculated based on available historical data } \\
\text { and individual risk assessment, } \\
\text { - high guarantee amount }\end{array}$ \\
\hline Distribution and marketing & $\begin{array}{l}\text { sold via unconventional intermediaries, often microfinance } \\
\text { institutions }\end{array}$ & $\begin{array}{l}\text { sold with the help of licensed insurance intermediaries } \\
\text { or directly to individual clients and entrepreneurs }\end{array}$ \\
\hline Insurance premium & irregular, cash, split in instalments & regular premiums, usually paid in a non-cash form \\
\hline Claim settlement & a simplified and easy procedure with low insurance sums & $\begin{array}{l}\text { a complex process requiring the involvement } \\
\text { of significant human resources and associated with } \\
\text { extensive documentation }\end{array}$ \\
\hline
\end{tabular}

Source: own work, Sigma, Swiss Re (2010).

It is worth noting that in the canon of microinsurance definitions one can find many interpretations, which are given both by insurance institutions (for example the International Association of Insurance Supervisors), as well as many researchers dealing with the issue of microfinance. Nevertheless, the common denominator that links them together is the target group of the so-called low-income recipients, who are often socially marginalized.

\section{Types and possibilities of microinsurance in the aspect of financial exclusion}

The largest share in the provision of microinsurance is held by professional insurers and reinsurers operating internationally, including: Interpolis $\mathrm{Re}, \mathrm{Axa} \mathrm{Re}$, Swiss Re, Munch Re, etc. Microinsurance covers three basic product groups: life, health, and property insurance. The estimates of Swiss Re and the World Bank indicate that 135 million people currently have microinsurance, which is about $5 \%$ of the potential market, ranging from 1.5 to 3 billion people (Biener, 2010, p. 8). On the other hand, the microinsurance market is presented in Figure 2.

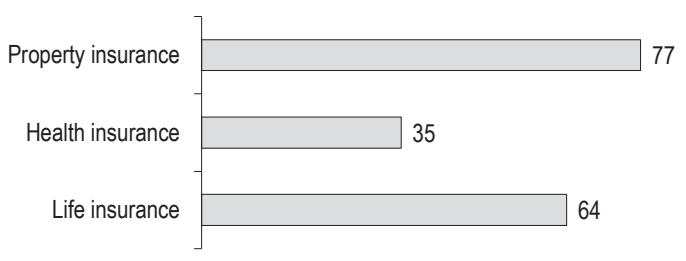

Figure 2. Global insurance market (in million USD, 2016)

Source: Microinsurance Network (2017).

Life insurance is among the products that enjoy the most popularity. It is part of micro-credit packages, including accident, disability and funeral costs insurance. In this group, life microinsurance with capital funds is less popular. The other group consists of micro-health insurance (primary care, hospitalization, maternity), which 
is mainly offered by non-governmental organizations, and is subsidized in many situations. On the other hand, property insurance provides financial protection of tangible assets against the basic risks in this respect, i.e.: fire, theft, flood, etc.

Microinsurance is offered in the form of individual insurance products as well as package products and index insurance.

In broader terms, this catalogue includes the following microinsurance products - Table 2, which also have the following advantages.

Tahle 2. Types of mainstay microinsurance products and benefits

\begin{tabular}{lll}
\hline \multicolumn{1}{c}{ Products } & \multicolumn{1}{c}{ Sub-types } & \multicolumn{1}{c}{ Benefits } \\
\hline Health & Hospitalisation, primary care, critical illness & $\begin{array}{l}\text { Protects the beneficiaries against illness, injury, diseases, coverage often } \\
\text { limited to hospitalization }\end{array}$ \\
\hline Life-Credit & Life protection (bundled with micro credit) & $\begin{array}{l}\text { Protects the lender for credit loss resulting from the death of the borrower, } \\
\text { offers limited value }\end{array}$ \\
\hline Life-Protection & Term life, funeral accident, disability & $\begin{array}{l}\text { Provides monetary benefits to the beneficiary in the event of death (accident) } \\
\text { disability of the policyholder }\end{array}$ \\
\hline Life-Savings & Endowment, pensions, investments & $\begin{array}{l}\text { Combination of savings and protection, mobilises savings for the policyholder } \\
\text { dependents }\end{array}$ \\
\hline Agriculture/Index & Crop insurance, livestock and index covers & $\begin{array}{l}\text { Protects agricultural income/returns from weather events pest infections, } \\
\text { catastrophes, etc. }\end{array}$ \\
\hline Assets & House/huts, business assets & $\begin{array}{l}\text { Usually linked with loans, indemnifies the beneficiary in case of loss of covered } \\
\text { assets due to named perils }\end{array}$ \\
\hline Microtacaful & Family takaful and general takaful & \begin{tabular}{l} 
Offers shariah-compliant insurance to low-income Islamic population \\
\hline
\end{tabular}
\end{tabular}

Source: Sigma, Swiss Re (2010).

New microinsurance products are being designed and launched for the benefit of low-income individuals in emerging markets. Many of these products feature innovative designs, leverage extensively on new technologies and make use of various conventional and alternative channels. There is continuous drive for innovation by risk carriers and distributions as they look for the optimal solutions to meet the needs of the low-income population, reduce transaction costs and expand the reach.

The following arguments support the development of microinsurance in the context of financial exclusion. Microinsurance is a simple instrument in combating poverty and secondary illiteracy, which also allow shaping the knowledge and insurance culture of the poorest individuals. Moreover, it is possible to include these products in the so-called misselling transactions, a fact which, in turn, increases the development of the insurance market as a part of the financial market. Microinsurance can also contribute to the development of insurance education and increase trust in insurers.

At the same time, microinsurance may also be a form of social entrepreneurship, which can also be effectively developed on the level of sustainable social development.

\section{Conclusions}

Nowadays, financial education is a key condition for the development of the financial market, including microinsurance. Without knowledge about not only the benefits, but also the risks that the purchase of insurance 
brings, even the poorest consumers will not be able to choose the product that best suits their needs. Financial knowledge facilitates proper management of even low income and affects the development of financial culture. The success of microinsurance programs in practice comes down to the use of innovative insurance distribution channels. Another solution is also introducing system incentives that encourage people to purchase insurance, e.g. subsidies or tax reliefs. The awareness campaigns carried out in the press and various media are also necessary. This task should be implemented by insurance institutions.

Thus, despite the fact that the problem of microinsurance is developing quite slowly and is still considered the product associated mainly with the poorest countries, microinsurance constitutes a significant market potential also for developing and developed countries. The insurance gap in these markets remains high. This, however, requires the adoption of an appropriate strategy by insurers, who should skilfully recognize the insurance needs of people affected by financial exclusion in this respect and use this opportunity to create an offer of microinsurance products. They are the main suppliers of these products, as the possibilities of developing an alternative market are currently very small.

\section{References}

Bednarczyk, T.H. (2016). Mikroubezpieczenia - innowacja produktowa czy powrót do korzeni? Prace Naukowe Uniwersytetu Ekonomicznego we Wrocławiu, 415, 23-32.

Biener, Ch. (2010). Mikroversicherung: Eine ökonomische Perspektive. Materials from the congress, Vortrag auf dem WiMa Kongress, Ulm, pp. 1-15.

Czapiński, J., Panek, T. (eds.) (2015). Diagnoza społeczna 2015. Warunki i jakość życia Polaków. Warszawa: Rada Monitoringu Społecznego.

Eling, M., Biener, Ch. (2011). Mikroversicherung: Profitabilität und Wachstumschansen in Zukunftsmärkten? Kreditwesen, 8, 403-404.

Financial Services Provision and Prevention of Financial Exclusion (2008). European Commission. VC/2006/0183, pp. 25-32. Retrieved from: https://ec.europa.eu/social/BlobServlet?docld=761\&langld=en.

Kawiński, M. (2010). Instytucja mikroubezpieczeń. in: T. Szumlicz (ed.), Społeczne aspekty rozwoju rynku ubezpieczeniowego (pp. 311-324). Warszawa: Oficyna Wydawnicza SGH.

Kempson, E., Whyley, C. (1999). Kept Out or Opted Out? Understanding and Combating Financial Exclusion. Bristol: Policy Press.

Microinsurance Network (2017). Annual Report 2016. Retrieved from: https://microinsurancenetwork.org/sites/default/files/ Microinsurance\%20Network_Annual\%20Report\%202016.pdf.

Sigma, Swiss Re (2010). Microversicherung - risikoschutz für 4 Miliarden Menschen. N'6 (pp. 1-40). Retrieved from: http://www. nepalimed.ch/diverses/sigma6_2010_de.pdf.

Singh, A., Bihari, N. (2018). A Decade since the First Microinsurance Regulations in India. Bimaquest, 18 (1), 40-58.

Solarz, M. (2011). Wybrane sposoby ograniczania zjawiska wykluczenia ubezpieczeniowego. Annales Universitatis Mariae Curie Sklodowska. Sectio H. Oeconomia, 45 (2), 363-371.

Cite this article aS: Bera, A. (2018). Microinsurance in limiting insurance exclusion. European Journal of Service Management, 4 (28/2), 65-71. DOI: 10.18276/ejsm.2018.28/2-07. 